\title{
Effects of abomasal infusion of cottonseed oil and dietary enzyme supplementation on dairy goats
}

\author{
G. Jalilvand ${ }^{1}$, A. Naserian ${ }^{2}$, N.E. Odongo ${ }^{3,4}$, E. Kebreab ${ }^{3}$, \\ R. Valizadeh ${ }^{2}$, F. Eftekhar Shahrodi ${ }^{2}$ and J. France ${ }^{3}$ \\ ${ }^{1}$ Department of Animal Science, Faculty of Agriculture, University of Zabol \\ Zabol, 98615-538 Iran \\ ${ }^{2}$ Department of Animal Science, Faculty of Agriculture, University of Ferdowsi \\ Mashhad, 91775-1163 Iran \\ ${ }^{3}$ Centre for Nutrition Modelling, Department of Animal and Poultry Science, University of Guelph \\ Guelph, Ontario, N1G 2W1 Canada
}

(Received 27 April 2007; revised version 13 July 2007; accepted 6 September 2007)

\begin{abstract}
Three lactating multiparous Sannen dairy goats in late lactation (146 \pm 7 days of milk) were used in a $3 \times 3$ Latin square design to determine the effects of abomasal infusion of cottonseed oil and dietary enzyme supplementation on milk yield and composition. Treatments were twice daily abomasal

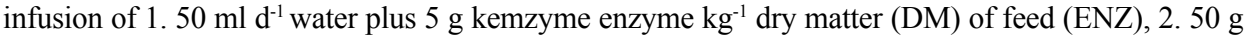

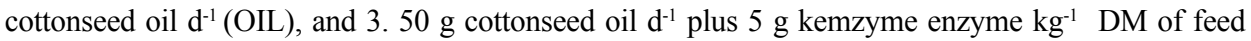
(ENZ+OIL). Goats were fed a basal diet of $40 \%$ lucerne hay and $60 \%$ concentrates offered ad libitum. Each experimental period consisted of 14 days of adaptation and 5 days of total collection. Abomasal infusion of cottonseed oil decreased $(\mathrm{P}<0.05) \mathrm{DM}$ intake and increased $(\mathrm{P}<0.05)$ milk fat percentage. Dietary supplementation of enzyme in the diet increased $(\mathrm{P}<0.05) \mathrm{DM}$ and organic matter $(\mathrm{OM})$ intake but had no effect $(\mathrm{P}>0.05)$ on apparent digestibility of $\mathrm{DM}, \mathrm{OM}$, crude protein, acid detergent fibre, neutral detergent fibre and ether extract. Cholesterol and plasma triglycerides increased $(\mathrm{P}<0.05)$ with cottonseed oil infusion but infusion of cottonseed oil with dietary enzyme supplementation had no $(\mathrm{P}>0.05)$ added benefit on lactational performance of the goats. These results suggest that abomasal infusion of cottonseed oil increased the amount of lipids reaching the mammary tissues and therefore increased milk fat percentage without altering milk yields.
\end{abstract}

KEY WORDS: abomasal infusion, cottonseed oil, kemzyme enzyme, feed intake, digestion, milk production, dairy goat

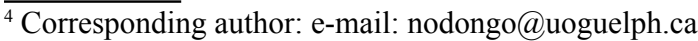




\section{INTRODUCTION}

Several studies have shown that fibrolytic enzymes can increase milk yield in dairy cows fed forage-based (Schingoethe et al., 1999; Yang et al., 1999), and concentrate-based diets (Rode et al., 1999). Several studies have reported no effects of fibrolytic enzymes on milk yield (e.g., Rode et al., 1999; Kung et al., 2002) whereas other have reported negative effects (Dhiman et al., 2002; Knowlton et al., 2002). Increased dry matter intake (DMI) with dietary enzyme supplementation have been observed in several studies (e.g., Lewis et al., 1999; Beauchemin et al., 2000). However, other authors have also reported no effects of dietary enzyme supplementation on DMI (Rode et al., 1999; Kung et al., 2000, 2002). Although the reasons for these conflicting results are unknown, it has been suggested that the increased DMI observed in some studies with dietary enzyme supplementation may have been due to increased palatability or higher rate of passage of feed through the digestive tract (Beauchemin et al., 2000).

In lactating dairy cows, it was shown that when 1.0 to $1.1 \mathrm{~kg} / \mathrm{d}$ of rape seed oil was infused directly into the proximal duodenum, oil-free DM intake was lower in oil-infused than in control cows (Gagliostro and Chilliard, 1991). It has also been shown that abomasal infusion of unsaturated long-chain fatty acid decreased DMI (Drackley et al., 1992; Benson et al., 2001; Litherland et al., 2005). However, little work has been done to investigate the combined effect of oil infusion and dietary enzyme supplementation in ruminants. The objective of this study, therefore, was to determine the effects of abomasal infusion of cottonseed oil and dietary enzyme supplementation on DMI, plasma metabolite and milk yield and composition in dairy goats.

\section{MATERIAL AND METHODS}

\section{Animals and treatment}

The experiment was conducted at the Animal Research Station, Ferdowsi University of Mashhad (Iran). Three multiparous Saanen dairy goats in late lactation (146 \pm 7 days in milk; $40 \pm 3.8 \mathrm{~kg}$ of body weight) were fitted with flexible abomasal cannulae and placed in individual crates in a $3 \times 3$ Latin square design. The treatments consisted of twice daily abomasal infusion of $1.50 \mathrm{ml}$ $\mathrm{d}^{-1}$ water plus $5 \mathrm{~g}$ kemzyme enzyme kg-1 DM of feed (ENZ), $2.50 \mathrm{~g}$ cottonseed oil $\mathrm{d}^{-1}$ (OIL), and 3. $50 \mathrm{~g}$ cottonseed oil $\mathrm{d}^{-1}$ plus $5 \mathrm{~g}$ kemzyme enzyme $\mathrm{kg}^{-1} \mathrm{DM}$ of feed (ENZ+OIL). Each experimental period consisted of 19 days; 14 days of dietary adaptation and 5 days of milk, rumen fluid and blood sample collection. 
The cottonseed oil was infused in two equal proportions at each feeding whereas the enzyme was top-dressed on the total mixed ration (TMR) $24 \mathrm{~h}$ before feeding. The enzyme used was a powdered multi-enzyme feed additive called Kemzyme (Kemin, Belgium) obtained commercially. According to the manufacturer, the supplement contained 5000 units (U) of cellulase, $20000 \mathrm{U}$ xylanase, $3000 \mathrm{U}$ ß-glucanase, $450 \mathrm{U}$ protease, $540 \mathrm{U}$ amylase and $100 \mathrm{U}$ lipase per gram of enzyme. The goats were fed a basal diet of $40 \%$ lucerne hay and $60 \%$ concentrates offered as a TMR for ad libitum intake in two equal meals at 08.00 and $20.00 \mathrm{~h}$. The ingredient and chemical composition of the basal diet is presented in Table 1. Clean, fresh water was available at all time. Before the start of the experiment, the goats were treated against internal parasites and vaccinated for enterotoxaemia.

Table 1. Ingredients and chemical composition of diet, \%, DM

\begin{tabular}{|c|c|c|c|}
\hline Ingredients & $\%$, DM basis & Composition & $\%$, DM basis \\
\hline Lucerne hay & 40 & $\mathrm{NE}_{1}$, Mcal kg-1 & 1.62 \\
\hline Barley grain & $32 / 34$ & Crude protein & 15.26 \\
\hline Beet pulp, dried & 14 & NDF & 36.70 \\
\hline Wheat bran & 8 & $\mathrm{ADF}$ & 21.14 \\
\hline Cottonseed meal & 5 & $\mathrm{Ca}$ & 0.8 \\
\hline Dicalcium phosphate & 0.18 & $\mathrm{P}$ & 0.43 \\
\hline Limestone & 0.18 & & \\
\hline Premix ${ }^{\text {a }}$ & 0.18 & & \\
\hline Common salt & 0.12 & & \\
\hline
\end{tabular}

${ }^{a}$ Premix: containing, $\mathrm{mg} \mathrm{kg}^{-1}$ : Zn 15000; Mn 12000; Fe 7500; I 4000; Co 50; Se 50; Mg 5.6; IU kg-1 : vit. A 3500000; vit. D3 862500; vit. E 4000

\section{Sampling and analysis}

At $08.00 \mathrm{~h}$ of each day after the collection of orts, the goats were hand-milked and individual milk yields recorded and the goats offered their feed allocation for the day. A sample of the milk was also obtained for compositional analysis (Milkoscan 605, Foss, Denmark). The feed offered and orts for each goat were recorded and a sub-sample of approximately $10 \%$ was collected and stored at $-20^{\circ} \mathrm{C}$ until the end of the experiment for subsequent analysis. On $\mathrm{d} 5$ of the collection period, blood was obtained by venipuncture of the jugular vein into EDTA-containing vacuum tubes (Vacutainer, Becton-Dickinson, Rutherford, NJ) $2 \mathrm{~h}$ after feeding. The blood samples were immediately cooled in ice and then centrifuged at $3000 \mathrm{~g}$ for $15 \mathrm{~min}$ to obtain plasma which was stored at $-20^{\circ} \mathrm{C}$ until analysis. The plasma samples were analysed for glucose and urea nitrogen using the enzymatic method of Sigma Diagnostics (St. Louis, MO) and triglycerides and cholesterol by infrared spectrophotometry. Rumen fluid samples were also collected from each goat on d 5 using a Geishauser oral probe (Geishauser, 1993) 
and strained through two layer of cheesecloth. The $\mathrm{pH}$ of the rumen fluid was then determined using a $\mathrm{pH}$ meter (Metrohm, 691, Swiss). Rumen liquor was centrifuged at $3000 \mathrm{~g}$ for $10 \mathrm{~min}$ and a sub-sample of $10 \mathrm{ml}$ analysed for $\mathrm{NH}_{3}-\mathrm{N}$ (Kjeltec, 2300, Auto Analyzer, Tecator, Sweden).

During the collection period, total faeces was collected each day and weighed. The faeces was thoroughly mixed and a sub-sample taken and stored at $-20^{\circ} \mathrm{C}$ for later analysis. Urine was collected in plastic bottles under acid conditions by adding concentrated sulphuric acid (Fisher Scientific, Fairlawn, NJ) to the empty polyethylene urine collection bottles daily. The urine was mixed and aliquots $(10 \%)$ were taken each day for analysis. The feed and faecal samples were ovendried at $60^{\circ} \mathrm{C}$ to constant weight and then ground to pass through a $1-\mathrm{mm}$ screen and analysed for dry matter (DM), organic matter (OM), and ether extract (EE) according to AOAC (1990) and acid detergent fibre (ADF) and neutral detergent fibre (NDF) according to Van Soest et al. (1991). Non-casein $\mathrm{N}$ was determined by Kjeldahl analysis of the filtrate after precipitation with $10 \%$ acetic acid and $1 \mathrm{~N}$ sodium acetate and subsequent determination of the $\mathrm{N}$ content. Casein $\mathrm{N}$ was calculated as the difference between total $\mathrm{N}$ and non casein $\mathrm{N}$. True protein was calculated as the difference between total N and NPN, and whey protein calculated as the difference between true protein and casein (Rawland, 1938). The apparent digestibility coefficients of DM, OM, CP, EE, NDF, and ADF were calculated as ((intake-output)/intake). Nitrogen balance was calculated as described by Rawland (1938).

\section{Statistical analysis}

Data were analysed in a $3 \times 3$ Latin square design using the general linear model procedures of SAS (SAS, 1999). The model was:

$$
Y_{i j k}=\mu+G_{i}+P_{j}+T_{k}+E_{i j k}
$$

where: $Y_{i j k}=$ observation, $\mu=$ overall mean, $G_{i}=$ goat effect, $P_{j}=$ period effect, $T_{k}=$ treatment effect, $E_{i j k}=$ random error. Effects were considered significant at $\mathrm{P}<0.05$.

\section{RESULTS AND DISCUSSION}

Nutrient intake and apparent digestibility coefficients are presented in Table 2. Enzyme supplementation increased $(\mathrm{P}<0.05)$ total DMI and $\mathrm{OM}$ intake compared to oil infusion (OIL) (Table 2) in agreement with previous studies (e.g., Lewis et al., 1999; Beauchemin et al., 2000). However, other studies did not observe any enzyme effect on DMI (Rode et al., 1999; Kung et al., 2000, 2002). These contrasting results in response to enzyme supplementation are probably 
Table 2. Nutrient intake, apparent digestibility coefficient of goats in response to dietary enzyme supplementation (ENZ), abomasal infusion of cottonseed oil (oil) or both (ENZ+OIL)

\begin{tabular}{|c|c|c|c|c|}
\hline \multirow{2}{*}{ Item } & \multicolumn{3}{|c|}{ Treatment } & \multirow{2}{*}{ SEM } \\
\hline & ENZ & OIL & ENZ+OIL & \\
\hline \multicolumn{5}{|l|}{ Intake, $\mathrm{kg} \mathrm{d}$} \\
\hline DMI & $1.86^{\mathrm{a}}$ & $1.69^{\mathrm{b}}$ & $1.77^{\mathrm{ab}}$ & 0.016 \\
\hline $\mathrm{OM}$ & $1.72^{\mathrm{a}}$ & $1.56^{\mathrm{b}}$ & $1.69^{\mathrm{b}}$ & 0.007 \\
\hline $\mathrm{CP}$ & 0.28 & 0.25 & 0.26 & 0.005 \\
\hline NDF & 0.57 & 0.51 & 0.53 & 0.01 \\
\hline $\mathrm{ADF}$ & 0.32 & 0.27 & 0.29 & 0.006 \\
\hline $\mathrm{NE}_{1}$, Mcal kg ${ }^{-1} \mathrm{DM}$ & 3.02 & 2.85 & 2.95 & 0.033 \\
\hline \multicolumn{5}{|l|}{ Digestibility, \% } \\
\hline $\mathrm{DM}$ & 70.6 & 71.5 & 69.2 & 1.17 \\
\hline $\mathrm{OM}$ & 71.5 & 73.2 & 70.6 & 0.96 \\
\hline $\mathrm{CP}$ & 73.4 & 72.6 & 71.8 & 0.85 \\
\hline EE & 74.1 & 74.5 & 73.2 & 1.62 \\
\hline NDF & 54.2 & 54.8 & 53.0 & 0.99 \\
\hline $\mathrm{ADF}$ & 53.2 & 52.8 & 52.6 & 1.41 \\
\hline
\end{tabular}

values with different superscript letters ( $\mathrm{a}$ and $\mathrm{b})$ in a row differ significantly $(\mathrm{P}<0.05)$

according to Tukey test; SEM - standard error of the mean

due to differences in diet composition (Beauchemin et al., 1999) and enzyme application methods (Yang et al., 2000). The (ENZ+OIL) treatment was intermediate between enzyme supplementation and oil infusion but was not different $(\mathrm{P}>0.05)$ from the other two treatment groups. Although the mechanism with which the abomasal oil infusion reduces DMI is not fully understood, it has been suggested that this reduction in intake was probably due to increased level of some circulating gut peptide such as cholecystokinin (Palmquist, 1994; Benson et al., 2001) or increased plasma concentrations of glucagon-like peptide 1 (Litherland et al., 2005), neither of which were measured in this experiment.

There were no treatment differences $(\mathrm{P}>0.05)$ in $\mathrm{DM}, \mathrm{OM}, \mathrm{CP}, \mathrm{NDF}, \mathrm{ADF}$, and EE digestibility (Table 2). Although most of the published literature have reported increased total tract digestibility of DM, OM or both following treatment with a fibrolytic enzyme mixture (e.g., Rode et al., 1999; Yang et al., 1999; Beauchemin et al., 2000), other studies have reported no effect of exogenous fibrolytic enzyme on digestibility DM or OM (e.g., Lewis et al., 1999; McAllister et al., 1999, 2000; Yang et al., 2000) in agreement with the current study. In the present study, the elevated DM and OM intakes and unchanged apparent digestibility coefficient of the diet (Table 2) was probably accompanied by faster rate of ruminal and total tract rate of passage.

Milk yield and composition are presented in Table 3. There were no treatment difference $(\mathrm{P}>0.05)$ in milk yield and composition, except milk fat percentage. In dairy cows, Benson et al. (2001) reported that milk fat percentage 
Table 3. Milk yield, composition and efficiency of production of goat milk in response to dietary enzyme supplementation (ENZ), abomasal infusion of cottonseed oil (OIL) or both (ENZ+OIL)

\begin{tabular}{lcccc}
\hline \multirow{2}{*}{ Item } & \multicolumn{3}{c}{ Treatment } & \multirow{2}{*}{ SEM } \\
\cline { 2 - 4 } & ENZ & OIL & ENZ+OIL & \\
\hline Milk yield, kg d $^{-1}$ & 1.62 & 1.54 & 1.56 & 0.014 \\
FCM $^{1}$ 4\%, kg d & & 1.5 & 1.42 & 0.012 \\
Efficiency $^{2}$ & 1.47 & 1.44 & 0.801 & 0.016 \\
Fat, \% & 0.789 & 0.851 & $3.38^{\mathrm{ab}}$ & 0.022 \\
Protein, \% & $3.35^{\mathrm{a}}$ & $3.55^{\mathrm{b}}$ & 3.12 & 0.046 \\
Lactose, \% & 3.19 & 3.34 & 4.99 & 0.027 \\
SNF, \% & 4.92 & 5.03 & 8.61 & 0.051 \\
Total solids, \% & 8.53 & 8.76 & 12.00 & 0.097 \\
Casein, \% & 11.89 & 12.31 & 2.29 & 0.025 \\
True protein, \% & 2.37 & 2.44 & 2.86 & 0.045 \\
NPN, \% & 2.91 & 3.05 & 0.26 & 0.005 \\
Whey protein, \% & 0.28 & 0.29 & 0.56 & 0.035 \\
MUN, mg dl- & 0.53 & 0.61 & 10.8 & 0.27 \\
\hline
\end{tabular}

${ }^{1} \mathrm{FCM}$ - fat corrected milk

${ }^{2}$ efficiency of production - (FCM/DMI)

values bearing different superscript letters $(\mathrm{a}$ and $\mathrm{b})$ in a row differ significantly $(\mathrm{P}<0.05)$

according to Tukey test, SEM - standard error of the mean

was increased in response to oil infusion in midlactation, but not in early lactation and stated that when cows were in positive energy balance (such as in mid- or late lactation), supplemental fat were secreted in milk or used for body adipose tissue. There were no treatment difference $(\mathrm{P}>0.05)$ in fat corrected milk (FCM), protein and solids-not-fat (SNF), and efficiency (FCM/DMI; Table 3 ). Total solids, lactose, casein, true protein, NPN, whey protein and milk urea N were also not affected $(\mathrm{P}>0.05)$ by treatments in agreement with previous studies (e.g., Stokes, 1992) that have reported no change in milk composition when cows were fed enzyme-treated forages. The observation that the estimated daily $\mathrm{NE}_{\mathrm{L}}$ intake was unchanged by oil infusion in the present study suggests that DMI was being metabolically regulated to achieve energy homeostasis.

Rumen fermentation characteristic was relatively stable as evidenced by the lack of treatment effect $(\mathrm{P}>0.05)$ on rumen $\mathrm{pH}$, ammonia nitrogen, and fibre digestibility in agreement with previous studies. There were no treatments effects $(\mathrm{P}>0.05)$ on blood glucose, albumin and BUN concentrations. It has been reported that oil infusion in dairy cows did not alter ruminal $\mathrm{pH}$ and ammonia nitrogen, or blood glucose concentration (Drackley et al., 1992). Dietary supplementations with enzymes in dairy cows have also been shown not to effect ruminal $\mathrm{pH}$ or ammonia nitrogen (Yang et al., 1999). Goats had significantly greater concentrations of total cholesterol $\left(2.62,3.07\right.$ and $2.93 \pm 0.026 \mathrm{mmol} \mathrm{l}^{-1}$; mean \pm SE, respectively for ENZ, OIL and ENZ+OIL) and triglyceride $\left(0.31,0.36\right.$ and $0.33 \pm 0.006 \mathrm{mmol} \mathrm{l}^{-1}$; mean $\pm \mathrm{SE}$, respectively, for ENZ, OIL and ENZ+OIL) in plasma when infused with cottonseed oil. Post-ruminal infusions of rape seed oil (Gagliostro et al., 1991) or 
saturated or unsaturated fatty acid (Drackley et al., 1992) increased concentrations of cholesterol in the plasma of dairy cows. The intake of $\mathrm{N}$, excretion of $\mathrm{N}$ in faeces and urine, absorbed and retained $\mathrm{N}$ was not affected $(\mathrm{P}>0.05)$ by treatment in agreement with the observation of Knowlton et al. (2002).

\section{CONCLUSIONS}

Our results show that infusion of cottonseed oil into the abomasum of lactating dairy goats decreases dry matter intake (DMI) whereas enzyme supplementation increased DMI. Abomasal infusion of cottonseed oil or supplementation of enzyme had no effect on milk yield and milk composition, despite the increased milk fat percentage. Infusions of cottonseed oil did not alter $\mathrm{NE}_{\mathrm{L}}$ intake. These results suggest that abomasal infusion of cottonseed oil increased amount of lipids reaching the mammary tissues and therefore increased milk fat percentage without altering milk yield.

\section{REFERENCES}

AOAC, 1990. Association of Official Analytical Chemists, Official Method of Analysis. $15^{\text {th }}$ Edition. Washington, DC

Beauchemin K.A., Morgavi D.P., McAllister T.A., Yang W.Z., Rode L.M., 2001. The use of enzymes in ruminant diets. In: P.C. Garnsworthy, J. Wiseman (Editors). Recent Advances in Animal Nutrition. Nottingham University Press, Nottingham (UK), pp. 297-322

Beauchemin K.A., Rode L.M., Maekawa M., Morgavi D., Kampen R., 2000. Evaluation of a nonstarch polysaccharidase feed enzyme in dairy cow diets. J. Dairy Sci. 83, 543-553

Beauchemin K.A., Yang W.Z., Rode L.M., 1999. Effect of grain source and enzyme additive on site and extent of nutrient digestion in dairy cows. J. Dairy Sci. 82, 378-390

Benson J.A., Reynolds C.K., Humphries D.J., Rutter S.M., Beever D.E., 2001. Effects of abomasal infusion of long-chain fatty acids on intake, feeding behavior and milk production in dairy cows. J. Dairy Sci. 84, 1182-1191

Dhiman T.R., Zaman M.S., Gimenez R.R., Walters J.L., Treacher R., 2002. Performance of dairy cows fed forage treated with fibrolytic enzymes prior to feeding. Anim. Feed Sci. Tech. 101, $115-125$

Drackley J.K., Klusmeyer T.H., Trusk A.M., Clark J.H., 1992. Infusion of long-chain fatty acids varying in saturation and chain length into the abomasum of lactating dairy cows. J. Dairy Sci. $75,1517-1526$

Gagliostro G.A., Chilliard Y., 1991. Duodenal rapeseed oil infusion in early and midlactation cows. 2. Voluntary intake, milk production and composition. J. Dairy Sci. 74, 499-509

Galiostro G., Chilliard Y., Davicco M.J., 1991. Duodenal rapeseed oil infusion in early and midlactation cows. Plasma hormones and mammary apparent uptake of metabolites. J. Dairy Sci. 74, 1893-1903

Geishauser T., 1993. An instrument for the collection and transfer of ruminal fluid and for the administration of water-soluble drugs in adult cattle. Bovine Pract. 27, 38-42 
Knowlton K.F., McKinney J.M., Cobb C., 2002. Effect of a direct-fed fibrolytic enzyme formulation on nutrient intake, partitioning, and excretion in early and late lactation Holstein cows. J. Dairy Sci. 85, 3328-3335

Kung Jr. L., Cohen M.A., Rode L.M., Treacher R.J., 2002. The effect of fibrolytic enzymes sprayed onto forages and fed in a total mixed ration to lactating dairy cows. J. Dairy Sci. 85, 2396-2402

Kung Jr. L., Treacher R.J., Nauman G.A., Smagala A.M., Endres K.M., Cohen M.A., 2000. The effect of treating forages with fibrolytic enzymes on its nutritive value and lactation performance of dairy cows. J. Dairy Sci. 83,115-122

Lewis G.E., Sanchez W.K., Hunt C.W., Guy M.A., Pritchard G.T., Swanson B.I., Treacher R.J., 1999. Effect of direct-fed fibrolytic enzymes on the lactational performance of dairy cows. J. Dairy Sci. 82, 611-617

Litherland N.B., Thire S., Beaulieu A.D., Reynolds K., Benson J.A., Draekley J.K., 2005. Dry matter intake is decreased more by abomasal infusion of unsaturated free fatty acids than by unsaturated triglycerides. J. Dairy Sci. 88, 632-643

McAllister T.A., Oosting S.J., Popp J.D., Mir Z., Yanke L.J., Hristov A.N., Treacher R.J., Cheng K.J., 1999. Effect of exogenous enzyme on digestibility of barley silage and growth performance of feedlot cattle. Can. J. Anim. Sci. 79, 353-360

McAllister T.A., Stanford K., Bae H.D., Treacher R.J., Hristove A.N., Baah J., Shelford J.A., Cheng K.J., 2000. Effect of a surfactant and exogenous enzymes on digestibility of feed and on growth performance and carcass traits of lambs. Can. J. Anim. Sci. 80, 35-44

Palmquist, D.L., 1994. The role of dietary fats in efficiency of ruminants. J. Nutr. 124, 1377-1382

Rawland S.J., 1938. The determination of the nitrogen distribution in milk. J. Dairy Res. 9, 42-46

Rode L.M., Yang W.Z., Beauchemin K.A., 1999. Fibrolytic enzyme supplements for dairy cows in early lactation. J. Dairy Sci. 82, 2121-2126

SAS, 1999. Statistics, User's Guide, Version 6.12. SAS Institute Inc. Cary, NC

Schingoethe D.J., Stegeman G.A., Treacher R.J., 1999. Response of lactating dairy cows to a cellulase and xylanase enzyme mixture applied to forages at the time of feeding. J. Dairy Sci. 82, 996-1003

Stokes M.R., 1992. Effects of an enzyme mixture, an inoculant and their interaction on silage fermentation and dairy production. J. Dairy Sci. 75, 764-773

Van Soest P.J., Robertson J.B., Lewis B.A., 1991. Methods for dietary fiber, neutral detergent fiber, and non starch polysacharides in relation to animal nutrition. J. Dairy Sci. 74, 3583-3597

Yang W.Z., Beauchemin K.A., Rode L.M., 1999. Effects of enzyme feed additives on extent of digestion and milk production of lactating dairy cows. J. Dairy Sci. 82, 391-403

Yang W.Z., Beauchemin K.A., Rode L.M., 2000. A comparison of methods of adding fibrolytic enzymes to lactating cow diets. J. Dairy Sci. 83, 2512-2520 